\title{
DIFFERENCES IN NUTRITIVE AND BIOACTIVE COMPOUNDS CONTENT BETWEEN HYBRID AND OPEN-POLLINATED MAIZE VARIETIES
}

\author{
Vojka B. Babić*, Natalija B. Kravić, Jelena P. Vančetović, Nenad S. Delić, Slađana M. Žilić \\ Maize Research Institute, Zemun Polje, Slobodana Bajica 1, 11185 Belgrade, Serbia
}

\author{
*Corresponding author: \\ Phone: +381648406039 \\ Fax: +381113756707 \\ E-mail address: vbabic@mrizp.rs
}

\begin{abstract}
The contemporary trends in maize breeding are directed at identification of genotypes with improved grain quality for human consumption, industrial processing, and their incorporation into breeding programmes. In this study, three maize hybrids and three open-pollinated varieties (OPVs), differing in grain colour and type, were used to examine the differences in the total carotenoid content, the phenolic compounds profile and total antioxidant capacity (TAC). In addition, physical parameters, basic chemical composition, as well as the content of protein fractions in grain, were analysed. The multivariate approach through Principal Component Analysis (PCA) application contributed to better understanding of the complexity of the interdependence for maize grain quality parameters tested. From the aspect of different end use, better technological quality desirable for dry milling and snack food processing found in OPVs Osmak and Bosanac, as well as high content of bioactive compounds (i.e. TAC) exhibited by OPV Rumenka, make these genotypes superior compared to hybrids' varieties evaluated.
\end{abstract}

Key words: antioxidant capacity, carotenoids, grain type/colour, phenolic compounds, Zea mays L.

\section{INTRODUCTION}

Maize is the most important field crop in Serbia, and ranks among the first three in the world. It has been estimated that maize would take over the primacy in the field crop production by 2025 . Maize grain is predominantly processed into feed and industrial products (i.e. starch, glue, industrial alcohol, and ethanol fuel), while in Latin American and especially African countries, maize represents $30-50 \%$ of daily energy and protein intake in human nutrition (Badu-Apraku et al., 2013; Doria et al., 2015). In recent years, the in- creased frequency of allergies and intolerance to gluten and gluten-containing products has opened up new possibilities for exploitation of maize flour and products. Additionally, as a gluten-free cereal, maize is suitable for celiac consumption (De la Hera et al., 2014).

Native white and pigmented maize have been cultivated in South America, mainly in Peru and Bolivia, and it was used for the preparation of traditional drinks and desserts long before European settlers ar- 
rived. Likewise, old white maize populations used to have a significant role in the diet of Western Balkan people, particularly the poor ones (Babić et al., 2018). This is supported by the fact that a great number of accessions (approximately 700 out of 2217 landraces) collected in this region during the previous period belongs to the white maize and are maintained in the Maize Research Institute "Zemun Polje” gene bank. Even today, farmers in Serbia (about $86 \%$ ) grow small quantities of maize open-pollinated varieties (OPVs), usually white ones, predominantly for the preparation of traditional food and their own needs (Knežević-Jarić et al., 2014). The situation is similar in many European countries (Rodriguez et al., 2008; Bitocchi et al., 2009).

Currently, multi-coloured, red, purple, blue, and black maize varieties are produced only in small amounts for making specialty foods or for use in ornamentation due to their colourful appearance (Abdel-Aal et al., 2006). Since containing a wide range of anthocyanins, with cyanidin derivatives as the most dominant form, red and blue maize present exceptional sources of both high level of health beneficial phytochemicals (i.e. flavonoids, phenolic acids, $\beta$ carotene and lutein) and high antioxidant capacity (Tanaka et al., 2008; Žilić et al., 2012). Also, health-promoting effects of anthocyanins, including anti-inflammatory and anti-carcinogenic activity, prevention in cardiovascular disease, and obesity/diabetes control, are reported in numerous studies (He and Giusti, 2010).

For a long period, maize breeding has been focused on increased and stabile yield, while grain quality has received less attention. The contemporary trends are directed at scanning genetic resources with the aim to identify genotypes of improved grain quality for human consumption and for industrial processing, in order to incorporate them into breeding programmes. Studies on landraces and OPVs as dynamic populations, with distinct identity, high genetic divergence and adaptation to local agro-ecological conditions showed that variations in physical and biochemical characteristics of grain are notably greater compared to those found among modern maize hybrids (Žilić et al., 2012; Anđelković et al., 2016). This certainly makes them interesting not only from the aspect of breeding, but also for their use for special purposes (Vančetović et al., 2017). In addition, the knowledge of the chemical variability of OP varieties contributes to the rescue of that germplasm and could be of economic interest, especially to the pharmaceutical, cosmetic and food industries.

All these finding prompted us to evaluate differences between three maize hybrid and three OP varieties differing in grain colour, according to the content of bioactive compounds, especially phenolic compounds and carotenoids, as well as antioxidant capacity. In addition, physical properties, the content of basic chemical com-pounds and the content of protein fractions in grain, were evaluated. The aim was to examine the potential of the OP varieties tested; in nutrients and bioactive com-pounds contents, in order to be used as sources of genes for improved grain quality of modern maize hybrids.

\section{MATERIALS AND METHODS}

\section{Plant material}

Three maize hybrid and three openpollinated (OP) varieties differing in grain type and colour were evaluated in this study (Table 1). In 2016, the experiment was conducted at Zemun Polje, Belgrade vicinity, Serbia $\left(44^{\circ} 52^{\prime} \mathrm{N}, 20^{\circ} 19^{\prime} \mathrm{E}, 81 \mathrm{~m}\right.$ asl). The genotypes were sown in eight 6 $\mathrm{m}$ long rows, in two replications, according to completely randomized block design. The inter-row distance was $0.75 \mathrm{~m}$, while the intra-row spacing was $0.24 \mathrm{~m}$. Hybrid varieties were selfed and landraces were multiplied via pair crossing by hand (i.e. full-sibling). The average sample per replication represents the bulk of 5000 kernels from the 50 ears (e.g. 100 kernels per central part of ear). Standard cropping practices were applied.

\section{Extraction of phenolic compounds from maize flour}

For the detection of total phenolics, total flavonoids and phenolic acids, extracts were prepared from $0.5 \mathrm{~g}$ of flour tissue. After alkaline hydrolysis for $4 \mathrm{~h}$ at room 
Table 1.

Plant material evaluated

\begin{tabular}{llll}
\hline Genotype & Variety type & Kernel type & Kernel colour \\
\hline ZP 5048 & Hybrid & dent & red \\
ZP 633 & Hybrid & dent-like & yellow-orange \\
ZP 65647b & Hybrid & dent & white \\
Rumenka & Open-Pollinated Variety & dent-like & dark red \\
Bosanac & Open-Pollinated Variety & intermediate & yellow-orange \\
Osmak & Open-Pollinated Variety & flint-like & white \\
\hline
\end{tabular}

temperature using $10 \mathrm{~mL}$ of $4 \mathrm{M} \mathrm{NaOH}$, the extraction was done with ethyl acetate and diethyl ether $(1: 1, v / v)$ four times.

Five $\mathrm{mL}$ of combined extracts were evaporated under the $\mathrm{N}_{2}$ stream at $30{ }^{\circ} \mathrm{C}$ to dryness and final residues were redissolved in methanol (Žilić et al., 2016). The extracts were kept at $-70{ }^{\circ} \mathrm{C}$ until analyses. All extractions were performed in duplicate.

\section{Analysis of total phenolic content (TP)}

The total phenolic content was determined according to the Foline Ciocalteu procedure (Singleton et al., 1999). The content was expressed as $\mathrm{mg}$ of gallic acid equivalent (GAE) per $\mathrm{kg}$ of dry matter (d.m.).

\section{Analysis of total flavonoid content (TF)}

The total flavonoid content was determined according to Zhishen et al. (1999) and expressed as $\mathrm{mg}$ of catechin equivalent (CE) per kg of d.m.

\section{Analysis of total anthocyanin content (ANC)}

Anthocyanins were extracted from $80 \mathrm{mg}$ of maize flour mixed with $5 \mathrm{~mL}$ of methanol acidified with $1 \mathrm{M} \mathrm{HCl}(85: 15, \mathrm{v} / \mathrm{v})$. After shaking, the absorbance was measured at 535 and $700 \mathrm{~nm}$. The content was expressed as $\mathrm{mg}$ of cyaniding-3-glucoside equivalent (CGE) per $\mathrm{kg}$ of d.m. Details of the method are described by Žilić et al. (2019).

\section{Analysis of individual phenolic acids}

Chromatographic analyses were performed on the Thermo Scientific Ultimate 3000 HPLC with a photodiode array detector. Phenolic acids were separated on the Thermo Scientific Hypersil GOLD aQ C18 column $(150 \mathrm{~mm} \times 4.6 \mathrm{~mm}$, i.d., 3 $\mu \mathrm{m})$ using a linear gradient elution pro- gram with a mobile phase containing solvent $A$ (formic acid/ $\mathrm{H}_{2} \mathrm{O}, 1: 99, \mathrm{v} / \mathrm{v}$ ) and solvent $B$ (methanol) at a flow rate of 0.8 $\mathrm{mL} / \mathrm{min}$. The solvent gradient was programmed as described by Žilić et al. (2012). The chromatograms were recorded at $280 \mathrm{~nm}$ by monitoring spectra within the wavelength range of 190-400 $\mathrm{nm}$. Identified phenolic acid peaks were confirmed and quantified using the Thermo Scientific Dionex Chromeleon 7.2. chromatographic software (Žilić et al., 2016).

\section{Analysis of total carotenoids (TC)}

The reference method of Association of Official Analytical Chemists (AOAC) (1995) was used. Briefly, $8 \mathrm{~g}$ of the sample was extracted with $40 \mathrm{ml}$ of water-saturated 1-butanol for $30 \mathrm{~min}$. After centrifugation, the supernatant was measured at $435 \mathrm{~nm}$. The pigment content was calculated using the conversion factor of 1.6632 and expressed as $\mathrm{mg}$ of $\beta$-carotene equivalent $(\beta C E)$ per $\mathrm{kg}$ of d.m.

\section{Analysis of total antioxidant capacity (TAC)}

The antioxidant capacity of maize samples was measured according to the QUENCHER method described by Serpen et al. (2008), using ABTS (2,2-azino-bis/3ethil-benothiazoline-6-sulphonic acid). The total antioxidant capacity was expressed as Trolox equivalent antioxidant capacity (TEAC) in mmol of trolox per $\mathrm{kg}$ of $\mathrm{d} . \mathrm{m}$. (dry matter).

\section{Physical properties}

After measuring the kernel weight, pericarp (Per), germ and endosperm (End+Ger) were isolated by hand-dissection of duplicate samples previously soaked in water for $12 \mathrm{~h}$. After drying, weight of each kernel part was measured 
and its portion in the whole kernel weight was calculated. The percentage of a hard (HE) and a soft endosperm (SE) portion, as well as the milling resistance time (RT) were determined by Stenvert-Pomeranz method (Radosavljevic et al., 2000). The description of the method of the specific density (SD) and the flotation index (FI) was given in the study of Radosavljević et al. (2000).

\section{Analysis of basic chemical compounds}

The standard AOAC (1995) chemical methods were applied to determine contents of ash, oil, total proteins and cellulose. The results are given in percentages of dry matter (d.m.).

\section{Analysis of protein fractions}

Different protein fractions were obtained by successive extractions of maize flour with a series of solvents in a ratio of $1: 10$ w/v (Žilić et al., 2010). Distilled water, 0.5 $\mathrm{M} \mathrm{NaCl}$ and $70 \%$ ethanol were used to extract albumin, globulin and zein fractions, respectively. Albumins were separated from non-protein nitrogen by precipitation from the water soluble fraction with $10 \%$ trichloroacetic acid. The extraction of each protein fraction was done by repeated stirring, tree times for $30 \mathrm{~min}$ at $4{ }^{\circ} \mathrm{C}$, followed by centrifugation at $15000 \mathrm{~g}$ for 5 min. The nitrogen content was determined in extracts by the micro Kjeldahl method and the protein content was calculated by using the conversion factor of 6.25. The results are given as percentage of dry matter.

\section{Statistical analyses}

Statistical analyses were performed using the MSTAT-C programme for the analysis of variance (ANOVA) and the SPSS Statistics 23 (IBM, Armonk, New York, USA) for the Principal Component Analysis (PCA).

\section{RESULTS AND DISCUSSION}

ANOVA revealed significant differences between maize genotypes $(p \leq 0.01)$ for analysed bioactive compounds (Table 2), physical properties and chemical composition (Table 3 and 4). The highest content of phenolic compounds, including total phenolics, flavonoids and phenolic acids, was measured in the red hybrid ZP5048, as well as in red and yellow OPVs Rumenka and Bosanac (Table 2). White OPV Osmak had a higher content of phenolic compounds than white hybrid. In addition, yellow OPV Bosanac and yellow hybrid ZP633 had the highest i.e. the lowest content of ferulic acid, as a dominant phenolic acid in maize grain (Navarro et al, 2018). Detected only in red colored genotypes, red OPV Rumenka exhibited significantly higher content of anthocyanins compared to the red hybrid ZP5048 (22.32 vs. $1.34 \mathrm{mg} \mathrm{CGE} \mathrm{kg}{ }^{-1}$ ) (Table 2). Immersed in a cellulose matrix of pericarp, the anthocyanins of red colored maize, although water-soluble, are hardly accessible, making them more stable.

In maize grain, phenolic compounds, phenolic acids primarily, exist mainly in the insoluble bound form and accumulated in the outermost layers. Das and Singh (2016) reported $74-83 \%$ of bound phenolics in the pericarp, while the remaining fraction was accumulated in the embrio mainly. However, the bioavailability of bound phenolics is low. Despite of low bioavailability of ferulic acid from maize bran $(2.5-5 \%$ or even lower $0.4-0.5 \%)$ (Adam et al., 2002), unmodified after stomach and intestinal digestion, these phenolic compounds reach to the colon where exert their healthful benefits locally, preventing colon cancer (Ah-Hen et al., 2012).

Numerous studies reported health-promoted effects of carotenoid-rich foods. Although a minor component in cereals, carotenoid content is an important characteristic in the utilization of cereals. In study on carotenoids distribution in cereal grain, Ndolo et al. (2013) reported significant variability in level of TC $(p \leq 0.05)$ within cereal varieties. The authors reported the average TC in whole grain was 18.19 $\mathrm{mg} / \mathrm{kg}$ for yellow maize, which was in line with our findings (i.e. $16.35 \mathrm{mg} \beta C E \mathrm{~kg}^{-1}$

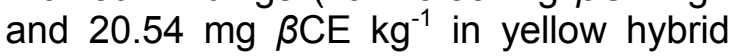
ZP633 and OPV Bosanac, respectively) (Table 2). Generally, white maize varieties, due to the presence of recessive homozygous mutation, are unable to accumulate high amounts of carotenoids (Lago et al., 2015), as was the case with 
ZP65647b and OPV Osmak, having negligible content of carotenoids (1.50 and $2.15 \beta C E \mathrm{~kg}^{-1}$, respectively). Since TC contributions to whole grain were the highest for the endosperm as the largest grain fraction (Coultate, 2009), low TC found in dark red OPV Rumenka is result of its white endosperm. Although exhibited high content of insoluble bound phenolic compounds, as well as carotenoids, OPV Bosanac does not contain bioactive compounds of extremely high antioxidant capacity. According to our results, anthocyanins seem to contribute the most to higher TAC, as was the case with red OPV Rumenka (Table 2).

Table 2.

Bioactive compounds content and antioxidant capacity of maize hybrids and OPVs

\begin{tabular}{lcccccccc}
\hline & TC $^{*}$ & TP $^{\#}$ & TF $^{\prime}$ & ANC $^{\prime}$ & CA & FA & TPA & TAC** $^{\text {* }}$ \\
\hline ZP 5048 & $22.27^{\mathrm{a}}$ & $3440.4^{\mathrm{b}}$ & $355.2^{\mathrm{a}}$ & $1.34^{\mathrm{b}}$ & $234.6^{\mathrm{c}}$ & $2024.4^{\mathrm{c}}$ & $2297.1^{\mathrm{c}}$ & $17.75^{\mathrm{b}}$ \\
ZP 633 & $16.35^{\mathrm{c}}$ & $2717.7^{\mathrm{b}}$ & $243.5^{\mathrm{c}}$ & n.d. & $288.2^{\mathrm{b}}$ & $1629.5^{\mathrm{f}}$ & $1934.6^{\mathrm{e}}$ & $10.30^{\mathrm{c}}$ \\
ZP 65647b & $1.50^{\mathrm{e}}$ & $2590.0^{\mathrm{d}}$ & $262.2^{\mathrm{c}}$ & n.d. & $172.5^{\mathrm{e}}$ & $1703.1^{\mathrm{e}}$ & $1889.2^{\mathrm{b}}$ & $11.85^{\mathrm{c}}$ \\
Rumenka & $7.60^{\mathrm{d}}$ & $3438.9^{\mathrm{b}}$ & $345.3^{\mathrm{a}}$ & $22.32^{\mathrm{a}}$ & $292.4^{\mathrm{a}}$ & $2138.1^{\mathrm{b}}$ & $2476.3^{\mathrm{b}}$ & $24.45^{\mathrm{a}}$ \\
Bosanac & $20.54^{\mathrm{b}}$ & $3469.4^{\mathrm{a}}$ & $343.3^{\mathrm{a}}$ & n.d. & $194.3^{\mathrm{d}}$ & $2289.7^{\mathrm{a}}$ & $2504.3^{\mathrm{a}}$ & $11.11^{\mathrm{c}}$ \\
Osmak & $2.15^{\mathrm{e}}$ & $2948.2^{\mathrm{c}}$ & $281.8^{\mathrm{b}}$ & n.d. & $148.6^{\dagger}$ & $1902.9^{\mathrm{d}}$ & $2070.3^{\mathrm{d}}$ & $11.74^{\mathrm{c}}$ \\
\hline
\end{tabular}

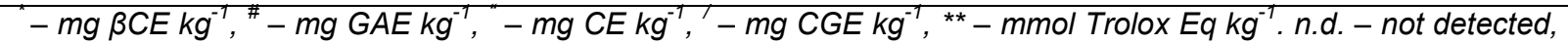
$T C$ - total carotenoids, TP - total phenolic compounds, TF - total flavonoids, ANC - total anthocyanins, TAC total antioxidant capacity, CA - p-coumaric acid, FA - ferulic acid, TPA - total phenolic acid

Table 3.

Physical properties and basic chemical composition of maize hybrids and OPVs

\begin{tabular}{lccccccccccc}
\hline & Per & EndGe & HE & SE & RT & SD & FI & Ash & Prot & Oil & Cel \\
\hline ZP 5048 & $5.79^{\mathrm{c}}$ & $94.21^{\mathrm{ab}}$ & 56.01 & 43.99 & $8.5^{\mathrm{c}}$ & 1.24 & 91.75 & 1.18 & $9.18^{\mathrm{d}}$ & 5.84 & $2.38^{\mathrm{a}}$ \\
ZP 633 & $5.01^{\mathrm{e}}$ & $94.99^{\mathrm{a}}$ & 62.78 & 37.22 & $10.0^{\mathrm{c}}$ & 1.22 & 23.37 & 1.32 & $9.01^{\mathrm{de}}$ & 5.01 & $2.21^{\mathrm{b}}$ \\
ZP & $5.51^{\mathrm{d}}$ & $94.48^{\mathrm{ab}}$ & 57.94 & 42.06 & $11.0^{\mathrm{b}}$ & 1.30 & 13.56 & 1.28 & $8.89^{\mathrm{e}}$ & 6.16 & $2.11^{\mathrm{b}}$ \\
Rumenka & $8.20^{\mathrm{a}}$ & $91.80^{\mathrm{c}}$ & 58.25 & 41.75 & $11.4^{\mathrm{b}}$ & 1.22 & 85.01 & 1.57 & 11.98 & 6.10 & $2.65^{\mathrm{a}}$ \\
Bosanac & $7.28^{\mathrm{b}}$ & $92.72^{\mathrm{bc}}$ & 67.45 & 32.54 & $16.0^{\mathrm{a}}$ & 1.32 & 12.06 & 1.42 & 10.99 & 5.88 & $2.06^{\mathrm{c}}$ \\
Osmak & $5.95^{\mathrm{c}}$ & $94.05^{\mathrm{ab}}$ & 66.17 & 33.83 & $14.0^{\mathrm{a}}$ & 1.27 & 49.85 & 1.43 & 11.23 & 6.58 & $2.24^{\mathrm{b}}$ \\
\hline
\end{tabular}

Per - percentage of pericarp portion in kernel weight, EndGer - percentage of endosperm and germ portion in kernel weight, HE - percentage of hard endosperm portion in kernel weight, SE - percentage of soft endosperm portion in kernel weight, RT - milling resistance time, SD - specific kernel density, FI - flotation index, Prot protein, $\mathrm{Cel}-$ cellulose

Table 4.

Content of protein fractions in maize hybrids and OPVs

\begin{tabular}{lcccc}
\hline & \multicolumn{3}{c}{ Content $^{*}$} \\
\cline { 2 - 5 } NonPN & Alb & Glb & Zein \\
\hline ZP 5048 & $0.92^{\mathrm{ab}}$ & $0.81^{\mathrm{a}}$ & $0.72^{\mathrm{a}}$ & $1.55^{\mathrm{d}}$ \\
ZP 633 & $0.89^{\mathrm{ab}}$ & $0.55^{\mathrm{b}}$ & $0.63^{\mathrm{b}}$ & $1.67^{\mathrm{c}}$ \\
ZP 65647b & $0.71^{\mathrm{c}}$ & $0.86^{\mathrm{a}}$ & $0.43^{\mathrm{c}}$ & $1.83^{\mathrm{b}}$ \\
Rumenka & $0.97^{\mathrm{a}}$ & $0.80^{\mathrm{a}}$ & $0.74^{\mathrm{a}}$ & $1.86^{\mathrm{b}}$ \\
Bosanac & $0.85^{\mathrm{b}}$ & $0.79^{\mathrm{a}}$ & $0.62^{\mathrm{b}}$ & $1.78^{\mathrm{c}}$ \\
Osmak & $0.62^{\mathrm{d}}$ & $0.81^{\mathrm{a}}$ & $0.61^{\mathrm{b}}$ & $2.51^{\mathrm{a}}$ \\
\hline
\end{tabular}

* - \% of protein fraction in dry matter, NonPN - free amino acids, Alb - albumin, Glb - globulin

Table 5.

Total percentage of variance explained by the PCA

\begin{tabular}{|c|c|c|c|c|c|c|}
\hline & \multicolumn{2}{|c|}{ Bioactive compounds } & \multicolumn{2}{|c|}{ Physical properties + BCCG } & \multicolumn{2}{|c|}{ Protein fraction } \\
\hline & EiV & $\mathbf{V}$ & EiV & V & EiV & $\mathbf{V}$ \\
\hline PCA1 & $5.63^{*}$ & 62.596 & $4.57^{*}$ & 45.724 & 2.72 & 54.307 \\
\hline PCA2 & $1.88^{*}$ & 20.873 & $4.43^{*}$ & 44.287 & $1.40^{*}$ & 27.998 \\
\hline PCA3 & $1.15^{*}$ & 12.786 & 0.63 & 6.323 & 0.82 & 16.362 \\
\hline PCA4 & 0.32 & 3.528 & 0.29 & 2.921 & 0.07 & 1.333 \\
\hline Cumulative & & 96.255 & & 90.002 & & 82.305 \\
\hline
\end{tabular}

EiV - Eigen value, ${ }^{*}$ - Eigen value > 1 considered as significant, V - Variance, BCCG - basic chemical composition of the grain 
Our findings are in line with previously reported superiority of OPV Rumenka regarding anthocyanin content and antioxidant capacity compared to hybrid varieties (Vančetović et al., 2012).

Observed significant difference regarding physical properties and basic chemical composition was found between genotypes evaluated (Table 3). Results of physical parameters (the milling response, portion of hard and soft fractions, density and flotation index) analysis confirmed the initial information on the grain type (Table 1). In addition, more pronounced pericarp portion, HE, RT, Ash, and Prot, was observed in OPVs compared to similarly coloured hybrids (i.e. red OPV Rumenka vs. red hybrid ZP5048). Obtained results pointed to better technological and nutritive grain quality of OPVs investigated (Žilić et al., 2012).

Maize proteins in grain, particularly zeins, influence the nutritional quality of the grain, the physical characteristics of grain and the functional characteristics of maize meal for making food products (Larkins, 2019). Yellow OPV had 5.0\% lower and $6.0 \%$ higher content of free amino acids and zein (Table 4), respectively, that contribute to superiority of its technological characteristics over yellow hybrid. It was not determined that observed differences in protein fractions attributed to the grain colour or type of variety (hybrid or OPV). Knowledge about the amount of protein in a seed and its amino acids composition has value, but information regarding the amount of protein in various solubility classes provides little biological insight or utility (Larkins, 2019). Certainly, the increased content of zein $(22.33 \%$ of total proteins) and the decreased content of non-protein nitrogen $(5.47 \%$ of total proteins) point out to the greatest kernel hardness of white OPV Osmak. Our results are in line with a fact that maize physical properties correlate well with total protein and zein subclasses (Lee et al., 2006). Some physical traits could be used to predict nutritional quality and utility value of maize kernel (Milašinović-Šeremešić et al., 2019). According to study of Žilić et al. (2010), the highest content of zein was in the popping maize grain and the lowest in sweet and dent hybrids grain. Compared to white OPV, the white hybrid ZP65647b is rich in albumins, the proteins superior in quality existing mainly in the germ.

\section{PC analysis}

Although ANOVA provided information on the existing levels of differences regarding observed parameters, it is difficult to establish their precise relationship with both, the grain colour/type and the type of variety. In this study, to explore similarities and hidden patterns among samples where relationship on data and grouping are still unclear (Granato et al., 2018), PCA was applied. The analysis was applied separately on three data sets: for bioactive compounds, combined physical properties and basic chemical composition of grain, as well as on protein fractions calculated on dry matter basis.

The PCA of bioactive compounds shows that the first three axes were significant, whereby total of $96.255 \%$ of data variability was covered with the first three axes (62.596, 20.873 and $12.786 \%$, respectively). For the rest of data sets, the first two PCA axes were significant, and the extent of the variation included can be seen in Table 5.

Generally, the parameters that define single axis (with rotated component matrix values $>0.7$ ) are in high correlation, while the parameters that define different axes are not correlated, which could be seen from the Table 6.

\section{PCA for bioactive compounds}

High correlations were observed between TP, TF, FA and TPA (explained by PCA1 axis). Also, high TAC was followed by high content of ANC and CA (explained by PCA2 axis), where content of TC, being independent from all of investigated bioactive compounds, was explained by PCA3 axis (Table 6, Figure 1a, b).

Compared to other genotypes evaluated, red OPV Rumenka and hybrid ZP5048 have a greater content of bioactive compounds (Figure 1a - PCA1-PCA2). Rumenka is characterized with the higher TAC, CA and ANC. On the other hand, 
ZP5048 has a higher content of TPA, TP, TF and FA, having in the same time low ANC and CA content, and as a consequence, less TAC compared to OPV Rumenka. OPV Osmak and ZP65647b, as white maize genotypes, have low content of all bioactive compounds (negative values of all three PCA axes). Yellow OPV Bosanac has a high content of TPA, TF, TP and FA, the lowest content of anthocyanins and $p$-coumaric acid and therefore low TAC. In Figure 1b (PCA1-PCA3), where the third axis is defined by the carotenoids content, has been shown that the genotypes ZP633, ZP5048 and Bosanac have the high carotenoids content, while ZP633 has a low contents of all other bioactive compounds. Although there are differences in physical and bio-chemical grain traits among modern maize hybrids, variation in these traits is substantially smaller compared to variation found in landraces and OP varieties. In the study of Anđelković et al. (2016), in the grain of 29 maize landraces, $\beta$-carotene content, by which the maize is generally poor, varied from 0.0 to $7.95 \mu \mathrm{g} / \mathrm{g}$.

Further, in the grain of seven colored maize landraces, the content of total anthocyanins ranged from 2.5 to $696.13 \mathrm{mg}$ CGE/kg (Žilić et al., 2012).

Table 6.

Component matrix(a) of PCAs

\begin{tabular}{|c|c|c|c|}
\hline \multirow{2}{*}{ Original Variables } & \multicolumn{3}{|c|}{ PCAs Components } \\
\hline & PCA1 & PCA2 & PCA3 \\
\hline \multicolumn{4}{|c|}{ Bioactive compounds } \\
\hline TAC & 0.380 & 0.905 & -0.032 \\
\hline $\mathrm{TP}$ & 0.900 & 0.266 & 0.306 \\
\hline TF & 0.931 & 0.297 & 0.141 \\
\hline ANC & 0.221 & 0.943 & -0.133 \\
\hline CA & -0.143 & 0.711 & 0.665 \\
\hline FA & 0.966 & 0.126 & -0.003 \\
\hline TPA & 0.904 & 0.316 & 0.155 \\
\hline $\mathrm{TC}$ & 0.430 & -0.168 & 0.886 \\
\hline \multicolumn{4}{|c|}{ Physical properties and basic chemical composition } \\
\hline END+GER & 0.129 & -0.928 & \\
\hline SD & 0.894 & -0.352 & \\
\hline $\mathrm{FI}$ & -0.857 & 0.309 & \\
\hline RT & 0.797 & 0.561 & \\
\hline HE & 0.892 & 0.298 & \\
\hline SE & -0.892 & -0.298 & \\
\hline Ash & 0.131 & 0.917 & \\
\hline Cel & -0.828 & 0.508 & \\
\hline Prot & 0.071 & 0.982 & \\
\hline Per & -0.129 & 0.928 & \\
\hline \multicolumn{4}{|c|}{ Protein fraction (d.m.) } \\
\hline NonPN & 0.985 & -0.110 & \\
\hline Alb & -0.235 & 0.969 & \\
\hline NonPN+Alb & 0.749 & 0.656 & \\
\hline Glb & 0.713 & -0.008 & \\
\hline Zein & -0.788 & 0.141 & \\
\hline \multicolumn{4}{|c|}{$\begin{array}{l}\text { TAC - total antioxidant capacity, TP - total phenolic compounds, TF - total flavonoids, ANC - total anthocyanins, } \\
\text { CA - p-coumaric acid, FA - ferulic acid, TPA - total identified phenolic acid, TC - total carotenoids, Per - } \\
\text { percentage of pericarp portion in kernel weight, End+Ger - percentage of endosperm and germ portion in kernel } \\
\text { weight, SD - specific kernel density, FI - flotation index, RT - milling resistance time, HE - percentage of hard } \\
\text { endosperm portion in kernel weight, SE - percentage of soft endosperm portion in kernel weight, Prot - protein, } \\
\text { Cel - cellulose, NonPN - free amino acids, Alb - albumin, Glb - globulin, d.m. - dry matter }\end{array}$} \\
\hline
\end{tabular}




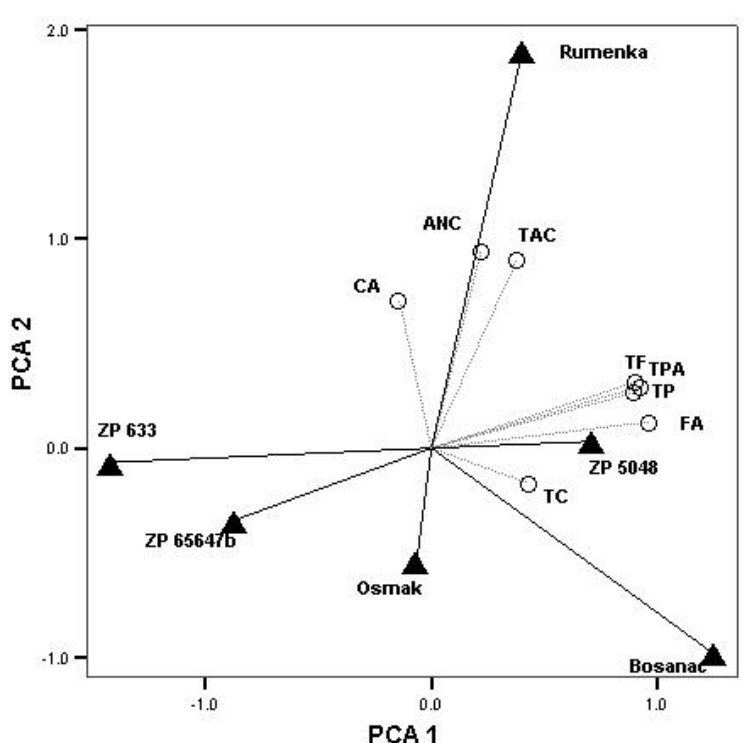

a)

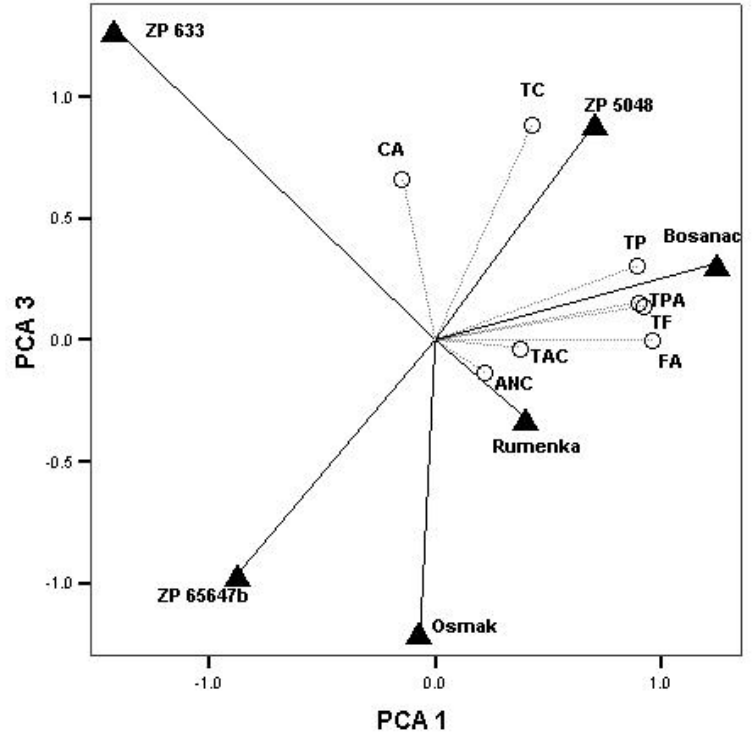

b)

Figure 1. PCA for bioactive compounds PCA1-2 (a) and PCA1-3 (b)

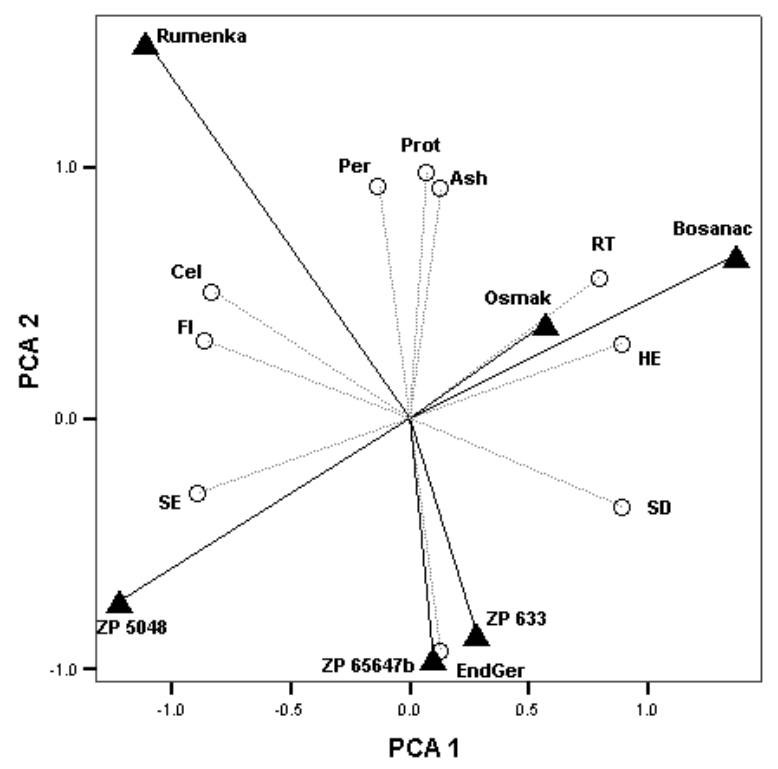

Figure 2. PCA for combined physical properties and basic chemical composition of grain

PCA for combined physical properties and basic chemical composition of grain

Values of the first axis, defined by the parameters related to kernel hardness (SD, FI, RT, HE, SE), and cellulose content (Cel), clearly separate genotypes with higher hardness (Bosanac, Osmak, ZP633, positive values of PCA1) from genotypes with high portion of SE, high FI and content of Cel (Table 6; Figure 2). It is clear that the values of the second axis, defined by Per, End+Ger, Ash, Prot and Per, clearly separate OPVs from hybrids (positive values on the second axis). OPVs are characterized by a greater portion of pericarp and Ash, followed by high protein content, compared to hybrids with greater portion of endosperm and germ. OPVs Osmak and Bosanac exhibited a 


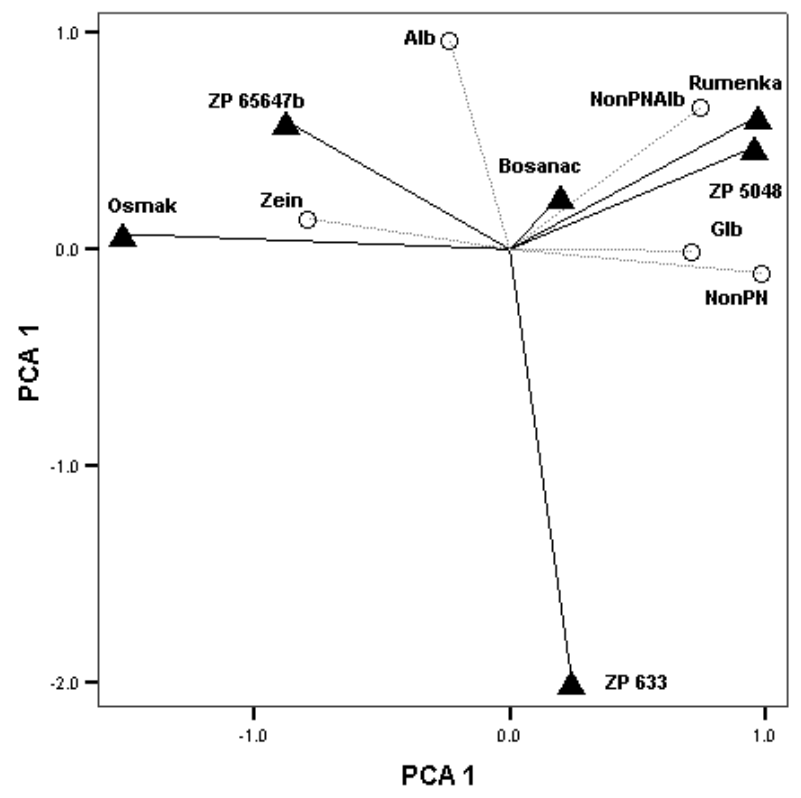

Figure 3. PCA for Protein fraction in d.m.

smaller content of cellulose and a greater content of the hard fraction (HE, RT, SD), indicated strongly the best technological quality and possibility for their direct application in food production, despite generaly lower OPV yield compared to hybrids ones. In our earlier studies (Babic et al., 2018), despite the lower grain yield, OPV Osmak had a protein yield per hectare above that of the ZP300b hybrid (FAO $300)$. Dry millers and snack food processors prefer hard-endosperm maize that results in higher flaking grit yield and more predictable cooking times (Paulsen et al., 2019).

Insufficient percentage of extracted data for variance explained by two PCA axes regarding oil content $(0.306$, data not presented) pointed out the necessity for separate observation of this parameter. The highest and the lowest oil content were recorded in white OPV Osmak and ZP633, respectively. Our findings are in line with reported a very few significant correlations between grain oil concentration and technological quality parameters. This is expected, since most kernel hardness and breakage susceptibility are associated with endosperm properties, while oil is largely found in the germ (Fox and Manley, 2009).

\section{PCA for protein fractions}

Considering the portion of protein fraction in dry matter, the first axis is defined by values of NonPN, NonPN+Alb, Glb and Zein, while the second axis is defined by values of Alb (Table 6). In Figure 3 (PCA1PCA2) has been shown a higher zein and a low globulin and free amino acids content in white maize genotypes, opposite to OPV Rumenka and ZP5048 (red), OPV Bosanac and ZP633 (yellow). Additionally, ZP633 is characterized by low content of almost all protein fractions, particularly albumin.

There is evidence that zein protein bodies contribute to the formation of vitreous regions of the mature maize kernel, although the mechanism by which this occurs is unclear (Larkins, 2019). Vitreous endosperm is the origin of grits, maize chips and flakes. While zein proteins are not nutritionally ideal, their hydrophobicity, abundance, and price have made them valuable for a variety of industrial applications as plasticizers, coatings, fibres, inks 
and mouldings (Lawton, 2002). For healthrelated reasons, plant-based zein biopolymers have advantages over those made from animal proteins (Demir et al., 2017). In that context, OPV Osmak could be recommended as a source for zein biopolymers extraction.

\section{CONCLUSION}

Simultaneous observation of combination of higher number of parameters through application of PCA provided comprehensive insight into the complexity of interrelations among observed parameters in grain of studied maize genotypes.

The multivariate approach made it possible to define genotypes with a combination of desirable traits for a particular type of an end use. Red OPV Rumenka exhibited the highest TAC due to high content of bioactive compounds. According to physical properties and basic chemical composition of grain, all OPVs are characterized with better technological quality, especially OPVs Osmak and Bosanac, making them desirable for dry milling and snack food processing. High content of zein found in OPV Osmak could have multiple uses in industrial applications as plasticizers, coatings, fibres, inks, and mouldings.

From the results obtained, it can be concluded that the maize OPVs evaluated represented the valuable genetic pools for commercial breeding material improvement, containing a wealth of benefits, including new opportunities for improving nutrition and multiple uses of maize and maize products.

However, besides of genetics, agroecological factors also have a significant impact on grain quality. In order to confirm the superiority of maize OPVs regarding nutritive and bioactive compounds content over hybrid maize varieties, further evaluation under contrasting environmental conditions will be conducted.

\section{ACKNOWLEDGEMENTS}

This study was supported by the "Science and Research Project of Maize Research Institute Zemun Polje", (contract no. 451-
03-68/2020), Ministry of Education, Science and Technological Development, Republic of Serbia.

\section{REFERENCES}

1. Abdel-Aal, E-S.M., Young, J.C., Rabalski, I. (2006). Anthocyanin composition in black, blue, pink, purple, and red cereal grains. Journal of Agriculture and Food Chemistry, 54, 4696-704.

2. Adam, A., Crespy, V., Levrat-Verny, M.A., Leenhardt, F., Leuillet, M. Demigné, C., Rémésy, C. (2002). The bioavailability of ferulic acid is governed primarily by the food matrix rather than its metabolism in intestine and liver in rats. Journal of Nutrition, 132, 1962-1968.

3. Ah-Hen, K., Fuenzalida, C., Hess, S., Contreras, A., Vega-Gálvez, A., Lemus-Mondaca, R. (2012). Antioxidant capacity and total phenolic compounds of twelve selected potato landrace clones grown in Southern Chile. Chilean Journal of Agricultural Research, 72, 1-9.

4. Anđelković, V., Mesarović, J., Srebrić, M., Kravić, N., Babić, V., Mladenović-Drinić, S. (2016). Evaluation of morphological and kernel micronutrient traits in maize landraces. Plant Breeding and Seed Production, 22, 39-48.

5. AOAC (1995). Official Methods of Analysis of AOAC International. 16th Ed., AOAC International, Washington, DC, USA.

6. Babić, V., Kravić, N., Živić, J., Srdić, J., Popović, A., Nikolić, A., Miritescu, M. (2018). Grain quality within ex situ and in situ conserved traditional white maize landraces. Romanian Agricultural Research, 35, 129-140.

7. Badu-Apraku, B., Oyekunle, M., Menkir, A., Obeng-Antwi, K., Yallou, C.G., Usman, I.S., Alidu, H. (2013). Comparative performance of early-maturing maize cultivars developed in three eras under drought stress and wellwatered environments in West Africa. Crop Science, 53, 1298-1311.

8. Bitocchi, E., Nanni, L., Rossi, M., Rau, D., Bellucci, E., Giardini, A., Buonamici, A., Vendramin, G., Papa, R. (2009). Introgression from modern hybrid varieties into landrace populations of maize (Zea mays ssp. mays L.) in central Italy. Molecular Ecology, 18, 603-621.

9. Coultate, T.P. (2009). Colours. In Food: The chemistry of its components. Ed. J. Rhodes, Royal Society of Chemistry, Cambridge, UK. 178-185.

10. Das, A.K., Singh, V. (2016). Antioxidative free and bound phenolic constituents in botanical fractions of Indian specialty maize (Zea mays L.) genotypes. Food Chemistry, 201, 298-306.

11. De la Hera, E., Talegón, M., Caballero, P., Gómez, M. (2014). Influence of maize flour particle size on gluten-free breadmaking. Journal of the Science of Food and Agriculture, 93, 924-932.

12. Demir, M., Ramos-Rivera, L., Silva, R., Nazhat, S.N., Boccanccini, A.R. (2017). Zein-based composites in biomedical applications. Journal of Biomedical Materials Research Part A, 105, 1656-1665.

13. Doria, E., Daoudou, B., Egal, A.K., OldewageTheron, W.H., Pilu, R. (2015). Preliminary ana- 
lysis and biochemical characterization related to health implications for African populations in some maize cultivars. A special look at the South African environment. Journal of Food Science and Nutrition, 1, 005.

14. Fox, G., Manley, M. (2009). Hardness Methods for testing maize kernels. Journal of Agricultural and Food Chemistry 57, 5647-5657.

15. Granato, D., Santos, J.S., Escher, G.B., Ferreira, B.L., Maggio, R.M. (2018). Use of principal component analysis (PCA) and hierarchical cluster analysis (HCA) for multivariate association between bioactive compounds and functional properties in foods: A critical perspective. Trends in Food Science and Technology, 72, 83-90.

16. He, J., Giusti, M.M. (2010). Anthocyanins: natural colorants with health promoting properties. Annual Review of Food Science and Technology, 1, 163-187.

17. Knežević-Jarić, J., Prodanović, S., Iwarsson, M. (2014). Decline of the maize landrace cultivation in Eastern Serbia. Romanian Agricultural Research, 31, 11-16.

18. Lago, C., Landoni, M., Cassani, E., Cantaluppi, E., Doria, E., Nielsen, E., Giorgi, A., Pilu, R. (2015). Study and characterization of an ancient European flint white maize rich in anthocyanins: Millo Corvo from Galicia. PloS one, 10, e0126521.

19. Larkins, B.A. (2019). Proteins of the Kernel. In Corn: Chemistry and Technology. Ed. S.O. Serna-Saldivar, Elsevier Inc., Amsterdam, Netherlands, pp. 319-336.

20. Lawton, J.W. (2002). Zein: A history of processing and use. Cereal Chemistry, 79, 1-18.

21. Lee, K., Bean, S.R., Alavi, S., Herrman, T.J., Waniska, R.D. (2006). Physical and biochemical properties of maize hardness and extrudates of selected hybrids. Journal of Agricultural and Food Chemistry, 54, 4260-4269.

22. Milašinović Šeremešić, M.S., Radosavljević M.M., Srdić Ž.J., Tomičić Z.M., Đuragić O.M. (2019). Physical traits and nutritional quality of selected Serbian maize genotypes differing in kernel hardness and colour. Food and Feed Research, 46 (1), 51-59.

23. Navarro, A., Torres, A., Fernández-Aulis, F., Peña, C. (2018). Bioactive compounds in pigmented maize. In Corn-production and human health in changing climate Eds. Amanullah and Shah Fahad, IntechOpen, pp. 69-91. Retrieved Feb. 2019 from https://www.intechopen.com/books/cornproduction-and-human-health-in-changingclimate/bioactive-compounds-in-pigmentedmaize

24. Ndolo, V.U., Beta, T. (2014). Comparative studies on composition and distribution of phenolic acids in cereal grain botanical fractions. Journal of Cereal Chemistry, 91, 522-530.

25. Paulsen, M.R., Singh, M., Singh, V. (2019).
Measurement and maintenance of corn quality. In Corn: chemistry and technology, Elsevier Inc., Amsterdam, Netherlands, 165-211.

26. Radosavljević, M., Bekrić, V., Božović, I., Jakovljević J., (2000). Physical and chemical properties of various corn genotypes as a criterion of technological quality. Genetika-Belgrade, 319-329.

27. Rodriguez, M., Rau, D., Papa, R., Attene, G. (2008). Genotype by environment interactions in barley (Hordeum vulgare L.): different responses of landraces, recombinant inbred lines and varieties to Mediterranean environment. Euphytica, 163, 231-247.

28. Serpen, A., Gökmen, V., Pellegrini, N., Fogliano, V. (2008). Direct measurement of the total antioxidant capacity of cereal products. Journal of Cereal Science, 48, 816-820.

29. Singleton, V.L., Orthofer, R., Lamuela-Raventos, R.M. (1999). Analysis of total phenols and other oxidation substrates and antioxidants by means of Folin-Ciocalteu reagent. Methods in Enzymology, 299, 152-178.

30. Tanaka, Y., Sasaki, N., Ohmiya, A. (2008). Biosynthesis of plant pigments: anthocyanins, betalains and carotenoids. The Plant Journal, 54, 733-749.

31. Vančetović J., Žilić, S., Božinović, S. (2012). ZP maize hybrids with red kernel. Plant Breeding and Seed Production, 18, 1-8.

32. Vančetović, J., Ignjatović-Micić, D., Trbović, D., Delić, N., Božinović, S., Nikolić, A., Kostadinović, M. (2017). Biochemical and physical kernel properties of a standard maize hybrid in different TopCross ${ }^{\mathrm{TM}}$ Blends. Scientia Agricola, 74, 461-468.

33. Zhishen, J., Mengcheng, T., Jianming, W. (1999). The determination of flavanoid contents in mulberry and their scavenging effects on superoxid radicals. Food Chemistry 64, 555-559.

34. Žilić, S., Ignjatović-Micić, D., Saratlić, G., Stanković, G., Delić, N., Filipović, M., Kresović B. (2010). Protein and tryptophan content in kernels of maize hybrids. Cotemporary Agriculture, 59, 56-64.

35. Žilić, S., Serpen, A., Akillioglu, G., Gokmen, V., Vančetović, J. (2012). Phenolic compounds, carotenoids, anthocyanins, and antioxidant capacity of colored maize (Zea mays L.) kernels. Journal of Agricultural and Food Chemistry, 60, 1224-1231.

36. Žilić, S., Kocadağlı, T., Vančetović, J., Gökmen, V., (2016). The effects of baking conditions and dough formulations on phenolic compounds stability, antioxidant capacity and color of cookies made from anthocyanin-rich corn flour. LWT - Food Science and Technology, 65, 597603.

37. Žilić, S., Dodig, D., Vančetović, J., Grčić, N., Perić, V., Titan, P., Maksimović, V. (2019). Composition of anthocyanins in colored grains and the relationship of their non-acylated and acylated derivatives. Polish Journal of Food and Nutrition Science, 69, 137-146. 


\section{РАЗЛИКЕ У САДРЖАЈУ ХРАНЉИВИХ И БИОАКТИВНИХ ЈЕДИЊЕЊА ИЗМЕЂУ ХИБРИДНИХ И СЛОБОДНООПРАШУЈУЋИХ СОРТИ КУКУРУЗА}

Војка Б. Бабић*, Наталија Б. Кравић, Јелена П. Ванчетовић, Ненад С. Делић, Слађана М. Жилић Институт за кукуруз, Земун Поље, Слободана Бајица 1, 11185 Београд, Србија

Сажетак: Савремени трендови у оплемењивању кукуруза иду у правцу идентификације генотипова повећаног квалитета зрна за људску употребу, индустријску прераду и њиховог укључивања у комерцијалне оплемењивачке програме. За ово истраживање одабране су три хибридне и три слободноопрашујуће сорте кукуруза различите по боји и типу зрна, у циљу испитивања разлика у садржају укупних каротеноида, фенолних једињења и укупном антиоксидативном капацитету. Додатно су анализиране фризичке карактеристике и основни хемијски састав зрна, као и садржај протеинских фракција. Мултиваријациони приступ, кроз примену анализе главних компонената (PCA) допринео је бољем разумевању сложених веза испитиваних параметара квалитета. Са аспекта различите употребне вредности, бољи технолошки квалитет пожељан за процес сувог млевења и процес производње грицкалица (снек производа) је идентификован код слободноопрашујућих сорти Осмак и Босанац, док се сорта Руменка одликовала високим садржајем биоактивних једињења (тј. високим антиоксидативним капацитетом). Добијени резултати указују на супериорност слободноопрашујућих сорти у поређењу са хибридним.

Кључне речи: антиоксидативни капацитет, каротеноиди, тип/боја зрна, френолна jeдињења, Zea mays $L$.

Received: 13 March .2020

Received in revised form: 28 April 2020

Accepted: 14 May 2020 